\title{
PEMAKNAAN PENGALAMAN HIDUP IBU DARI ANAK YANG MENGIDAP LEUKEMIA LIMFOBLASTIK AKUT
}

\author{
Anggita Hotna Panjaitan \& Winarini Wilman Mansoer \\ Universitas Indonesia, Jl. Margonda Raya No. 538, Pondok Cina, Kec. Beji, Depok 16424, Indonesia
}

Korespondensi: gita.panjaitan@gmail.com

\section{EXPLORATION OF THE MEANING MAKING EXPERIENCE OF MOTHERS WHOSE CHILDREN SUFFERED FROM ACUTE LYMPHOBLASTIC LEUKEMIA}

\section{Abstract}

This study aims to explore the experience of mothers whose children suffered from Acute Lymphoblastic Leukemia (ALL). Mothers of child with chronic diseases, such as ALL, have to manage their roles as a caregiver for their sick child, while also managing domestic responsibilities. Using phenomenological approach, the interviews and observations were conducted to two mothers whose at least one of their children were diagnosed with LLA when they were 7 and 9 years old. Data collections were conducted in two sessions. Six themes were emerged by the participants:1) overcoming a turning point of their lives, 2) the learning process, 3) receiving support, 4) connecting with God and people in similar situation, 5) no mother is perfect, and 6) one thing at a time. The result of this study can inform wider community, as well as relevant professional workers, to better understand the psychological dynamics of the mothers or caregivers and to assist in designing mental health support programs for the caregivers of children with chronic diseases.
Manuscript type: Original Research

Article history:

Received 26 December 2019

Received in revised form 11 April 2020

Accepted 3 July 2020

Available online 10 August 2020

\section{Keywords:}

caregiver

children with leukemia

leukemia

mother

mother's role

phenomenology

\begin{abstract}
Abstrak
Studi ini bertujuan untuk mengeksplorasi pengalaman ibu dengan anak yang menderita Leukemia Limfoblastik Akut (LLA). Ibu dengan anak yang mengidap penyakit kronis, seperti LLA, harus mengelola peran mereka sebagai seorang pengasuh untuk anak yang sakit, sekaligus menangani tanggung jawab domestik. Dengan menggunakan pendekatan fenomenologi, wawancara dan obervasi dilakukan kepada dua orang ibu yang memiliki beberapa anak, dan satu di antaranya mengidap LLA di usia 7 dan 9 tahun. Pengumpulan data dilakukan dalam dua pertemuan. Enam tema muncul dari dari partisipan: 1) mengatasi titik balik kehidupan mereka, 2) proses pembelajaran, 3) menerima dukungan, 4) keterhubungan dengan Tuhan dan orang-orang senasib, 5) tidak ada ibu yang sempurna, dan 6) satu hal dalam satu waktu. Hasil studi ini memberikan wawasan kepada komunitas yang lebih luas, serta praktisi profesional, untuk dapat memahami dengan lebih baik dinamika psikologis yang dialami para ibu atau pengasuh, serta untuk memberi informasi yang bermanfaat dalam merancang program dukungan kesehatan mental bagi pengasuh anak-anak dengan penyakit kronis.
\end{abstract}

Kata Kunci: anak dengan leukemia, fenomenologi, ibu, leukemia, pengasuh, peran ibu

\section{Dampak dan Implikasi dalam Konteks Ulayat}

Studi ini Jumlah anak yang menderita LLA di Indonesia meningkat dari tahun ke tahun. Dengan konteks budaya patriarkal di Indonesia yang menempatkan ibu sebagai pengasuh utama bagi anak, penelitian ini diharapkan dapat memberi tilikan bagi praktisi klinis untuk lebih memahami dinamika psikologis ibu sebagai pengasuh utama anak yang mengidap LLA, sehingga dapat memberi dukungan psikologis secara tepat. Penelitian ini juga diharapkan dapat menjadi bahan pertimbangan bagi institusi kesehatan untuk menyediakan layanan profesional guna menjaga kesehatan mental keluarga, terutama ibu, dengan anak yang menderita LLA, yang tentunya akan menunjang kesehatan mental anak. 


\section{PENDAHULUAN}

Berdasarkan data dari Kementrian Kesehatan Republik Indonesia (2015), setiap tahun terdapat sekitar 11,000 kasus kanker pada anak di tingkat nasional, sekitar 650 kasus di antaranya terjadi di Jakarta. Sepertiga dari penderita kanker anak tersebut didiagnosis dengan kanker darah atau yang dikenal dengan leukemia. Leukemia bermula ketika terjadi abnormalitas pada sumsum tulang belakang yang menghasilkan sel darah putih dalam jumlah banyak dan abnormal, sehingga mengganggu fungsi tubuh dalam melawan infeksi (Ramya \& Lakshmi, 2019). Sel darah putih yang abnormal menyerang sel darah yang sehat, sehingga jumlahnya berkurang dan tidak dapat menjalankan fungsi perlindungan pada tubuh secara optimal.

Leukemia Limfoblastik Akut (LLA) adalah kanker klonal dari sel-sel prekursor limfoid. Jenis leukemia ini adalah yang paling banyak terjadi pada anak-anak dan apabila tidak segera ditangani dapat berakibat fatal (Fianza, 2006). Beberapa faktor risiko dari leukemia, di antaranya predisposisi genetik dan faktor lingkungan, seperti radiasi, bahan kimia rumah tangga, dan obsesitas (Davis, Viera, \& Mead, 2014). Setiap anak yang menderita LLA memunculkan manifestasi klinis yang tidak spesifik, meliputi anemia, nyeri tulang dan sendi, demam, banyak berkeringat, infeksi mulut, pendarahan kulit, pendarahan gusi, hematuria, dan pendarahan pada saluran cerna (Behrman, Kliegman, \& Arvin, 2000). Teknik pengobatan yang telah terbukti dapat membantu untuk melawan sel kanker pada anak adalah kemoterapi dan radioterapi.

Kemoterapi dilakukan dengan pemberian obat-obat kimia pada penderita dengan rentang waktu 2-3 tahun (Coniglio \& Blackman, 1995). Dalam melakukan kemoterapi, terdapat beberapa tahapan yang harus dijalani, yaitu induksi, konsolidasi, dan perawatan (Cooper \& Brown, 2015). Fase induksi merupakan fase yang bertujuan untuk mencapai tahap remisi dengan kurang dari lima persen sel-sel leukemia pada sumsum tulang. Pada fase ini, pasien akan dirawat di rumah sakit dan menjalani serangkaian pemeriksaan serta kemoterapi. Ketika pasien sukses melewati fase induksi, mereka akan menjalani fase konsolidasi, di mana pasien menerima terapi guna membasmi sel-sel leukemia yang masih tersisa. Fase ketiga adalah fase perawatan yang merupakan fase terpanjang dari rangkaian kemoterapi. Pada fase ini, perawatan bersifat tidak intensif dan dapat dilakukan dengan rawat jalan selama 2-3 tahun. Kedisiplinan dalam menjalani fase ini terbukti efektif untuk mempertahankan status remisi pada penderita LLA (Cooper \& Brown, 2015). Sementara itu, pengobatan dengan radioterapi mencakup pengiriman radiasi dosis tinggi ke area tubuh di mana 
kanker menyerang. Pada umumnya, metode ini dilakukan sebagai kendali lokal pada beberapa jenis leukemia, saat kanker memengaruhi kelompok kelenjar getah bening tertentu.

Efek samping proses pengobatan leukemia pada anak meliputi efek fisik dan psikologis. Efek samping fisik, di antaranya kehilangan nafsu makan, pengurangan berat badan, alopesia (kerontokan rambut), memar, mimisan, mukositis, mual, muntah, dan diare (Cicogna, Nascimento, \& Lima, 2010). Sementara itu, efek samping psikologis meliputi rendahnya harga diri dan ketidakstabilan suasana hati (Sherief dkk., 2015). Pada dasarnya, leukemia tidak hanya berdampak pada kesehatan fisik dan psikologis dari anak yang mengidap, melainkan juga kehidupan seluruh anggota keluarga, baik orang tua maupun saudara kandung dari penderita. Dampak psikologis yang dialami orang tua, di antaranya mengalami kecemasan yang tinggi, stres, dan rasa takut yang besar (Bally dkk., 2014). Hal ini berpotensi mengusik kualitas hubungan dalam interaksi suami istri. Di samping itu, rendahnya harga diri pada anak juga mengakibatkan tingginya tingkat stres kedua orang tua dalam menghadapinya (Sherief dkk., 2015). Hal ini berpotensi menimbulkan tegangantegangan dalam interaksi kedua belah pihak.

Kehadiran anak yang mengidap leukemia dapat menyebabkan saudara kandung penderita merasa kurang diperhatikan (Major, 2003). Perhatian ibu yang dicurahkan kepada anaknya yang mengidap leukemia berpotensi membahayakan hubungan orang tua, terutama ibu dengan anak lainnya yang sehat. Hal ini dikaitkan dengan fokus ibu yang selalu dilimpahkan hanya kepada anaknya yang sakit, sehingga peran sebagai ibu bagi anak yang lain cenderung terbengkalai.

Macedo, Silva, Paiva, dan Ramos (2015) menyatakan bahwa ibu adalah sosok utama yang terlibat secara penuh dalam proses pengobatan anak dengan leukemia. Dengan kata lain, ibu adalah pengasuh (caregiver) utama dari anak yang mengidap leukemia. Pengasuh didefinisikan sebagai individu yang memiliki tanggung jawab untuk memberikan perawatan pada seseorang yang sakit, baik secara mental, fisik, kognitif, baik karena masalah fisik maupun karena penurunan fungsi akibat usia lanjut (Lubkin \& Larsen, 2013). Hal ini berkaitan dengan peran ibu yang secara umum memang dimaknai sebagai pengasuh dan perawat anak di dalam keluarga.

Berdasarkan penelitian Masako (2003), ibu memang dipandang memiliki peran yang khas di dalam tatanan rumah tangga, yaitu sebagai pengurus perawatan rutin domestik, seperti memberi makan, memasak, menyiapkan pakaian, dan menemani anak untuk belajar. Di Indonesia, sekalipun perkembangan era modern memberikan kesempatan kepada perempuan untuk mengenyam pendidikan yang tinggi dan mengejar karir profesional (Himawan, Bambling, \& Edirippulige, 
2017), para perempuan, khususnya ibu yang bekerja, tetap memegang peran domestik di dalam rumah tangga, sekaligus berperan sebagai sosok utama dalam merawat anak (Nurhamida, 2013).

Dalam konteks menjalani peran sebagai pengasuh keluarga dengan anak yang mengidap LLA, ibu juga memiliki peran ganda dalam keseharian. Ia harus bertanggung jawab dengan peran domestik di rumah, termasuk di dalamnya mendidik dan mengasuh anak-anak yang sehat serta perlu menjadi pengasuh utama bagi anaknya yang sakit agar dapat terus menjalani proses pengobatan secara maksimal. Kondisi ini menuntut ibu untuk mengelola fokus dan waktu pada aktivitas rutin di dalam keluarga, memperhatikan anak yang sakit, sekaligus membagi perhatian pada anak-anaknya yang lain. Peran ganda tersebut memengaruhi kesehatan psikologis para ibu (Katooa, Shahwan, Reece \& Jones, 2015).

Bally dkk. (2014) menyatakan bahwa para ibu dengan anak yang mengidap leukemia menghadapi perubahan besar dalam suasana hidup sehari-hari di rumah, meliputi kehilangan kegembiraan, depresi, bahkan mulai muncul pikiran untuk bunuh diri. Hal ini sejalan dengan penelitian Nayak, Cornelio dan George (2016) yang menyatakan bahwa sebagai individu, ibu mengalami proses berduka yang rumit dalam menerima diagnosis leukemia pada anaknya. Selain itu, Florian dan Krulik (1991) menyatakan bahwa ibu selaku pengasuh utama anak yang mengidap leukemia kerap mengalami kesepian. Jenis kesepian yang dialami bersifat eksistensial, yaitu perasaan subjektif yang meliputi perasaan putus asa, hampa, dan kehilangan yang dirasakan dan dihidupi secara personal dan mendalam, sehingga tidak mudah dihilangkan melalui hubungan sosial dengan orang di sekitarnya. Mereka juga mengalami duka yang kronis, yaitu perasan sedih yang progresif, persisten, dan tidak berujung (Nikfarid, Rassouli, Borimnejad, Alavimajd, 2017). Kemunculan duka kronis ini disebabkan oleh bayangan masa depan anak yang suram dan rasa takut atas bahaya dari penyakit kanker yang dapat merenggut nyawa anaknya. Di sisi lain, Nayak, Cornelio dan George (2016) menyatakan bahwa ibu dengan anak yang mengidap leukemia mengalami kesulitan untuk menjalani peran gandanya. Sekalipun tidak bekerja secara formal, para ibu merasa bahwa mereka mengalami kesulitan membagi fokus untuk mengasuh anak yang sehat, dan yang sakit sekaligus. Namun di sisi lain, mereka enggan berbagi perasaan dan beban mereka kepada suami, karena mereka merasa suami mereka telah terbebani dengan perannya untuk menghidupi keluarga sekaligus membiayai pengobatan anak mereka. Hal ini turut menciptakan beban mental sebagai pengasuh sekaligus sebagai ibu. Padahal, Macedo dkk. (2015) menyatakan bahwa kualitas hidup dan kualitas istirahat ibu merupakan hal yang penting untuk menunjang fungsi mental dan fisiknya dalam menjalankan peran yang optimal. 
Berdasarkan paparan di atas, ibu memiliki peran ganda yang sangat penting, baik dalam kehidupan keluarga secara umum, maupun sebagai pengasuh dari anak dengan leukemia. Beban psikologis yang diterima oleh seorang ibu dalam menerima diagnosis leukemia dari anaknya, tekanan dan tuntutan untuk menjaga dan merawat keluarga secara utuh merupakan hal yang berat untuk dijalani. Padahal, kondisi mental ibu merupakan salah satu faktor yang akan memengaruhi kualitas perawatan yang ia berikan kepada anaknya yang mengidap leukemia. Dengan mempertimbangkan semakin berkembangnya jumlah anak yang mengidap leukemia di Indonesia, maka kualitas kesehatan psikologis ibu juga perlu diperhatikan.

Di Indonesia, penelitian yang mengeksplorasi pengalaman ibu dari anak yang mengidap LLA masih sedikit, padahal jumlah anak yang mengidap LLA setiap tahun semakin meningkat (Departemen Kesehatan, 2015). Dalam sepuluh tahun terakhir, hanya terdapat dua penelitian mengenai pengalaman ibu dengan anak yang mengidap LLA (Maria, Indriati, \& Rahmalia, 2014; Rokhaidah \& Herlina, 2018). Kedua studi fenomenologis tersebut berfokus pada pengalaman ibu dalam melakukan perawatan kepada anak yang menderita LLA, namun tidak memperhitungkan peran ibu di dalam rumah tangga. Hal ini mendorong peneliti untuk memahami bagaimana pengalaman menjalani peran ibu sekaligus peran sebagai pengasuh dari anak yang mengidap leukemia, serta bagaimana mereka memaknai pengalamannya tersebut. Dengan pemahaman yang mendalam mengenai pengalaman ibu menjalani peran ganda tersebut, diharapkan masyarakat, lembaga kesehatan, bahkan praktisi klinis yang berkecimpung di ranah penyakit leukemia pada anak dapat memberikan perhatian dan penanganan psikologis yang tepat dan holistik untuk mendukung para ibu. Hal ini penting mengingat peran ganda ibu di dalam keluarga tidak dapat digantikan dan menentukan kualitas kesehatan, baik psikis maupun psikologis, keluarga dan anaknya yang mengidap leukemia.

\section{METODE}

\section{Partisipan}

Pemilihan partisipan pada penelitian ini menggunakan teknik purposive sampling. Karakteristik partisipan di penelitian ini adalah: 1) ibu yang memiliki lebih dari satu orang anak, dengan salah satu anak mengidap leukemia jenis LLA, 2) ibu memegang peran sebagai pengasuh utama dari anak tersebut selama proses perawatan, dan 3) ibu memiliki kemampuan berkomunikasi yang baik, ditandai dengan kemampuannya menceritakan pengalamannya kepada peneliti. Kriteria 
memiliki lebih dari satu anak ditetapkan untuk mengeksplorasi pemaknaan ibu dalam menjalani peran domestiknya mengurus keluarga, termasuk di dalamnya merawat seluruh anak dan rumah tangga (Masako, 2003), di mana di saat bersamaan menjadi pengasuh dari anak yang mengidap LLA.

Partisipan yang terlibat di dalam penelitian ini adalah dua orang ibu dengan anak yang mengidap leukemia jenis LLA yang menjalani proses pengobatan medis secara lengkap dan memiliki anak lainnya yang sehat, serta berperan aktif sebagai pengasuh utama dari anak yang mengidap LLA. Ibu RV berprofesi sebagai dokter umum, berusia 38 tahun, beragama Islam, memiliki tiga orang anak dengan satu orang anak mengidap leukemia, dan berdomisili di Jakarta. Anak dari ibu RV berjenis kelamin perempuan. Ia didiagnosis mengidap LLA di tahun 2014 ketika berusia tujuh tahun, dan saat data diambil akan memulai kemoterapi fase perawatan (fase ketiga). Sementara ibu EM adalah ibu rumah tangga, berusia 40 tahun, beragama Kristen, memiliki tiga orang anak dengan satu orang anak mengidap leukemia, dan berdomisili di Jakarta. Anak ibu EM berjenis kelamin perempuan. Ia didiagnosis mengidap LLA di tahun 2016 ketika berusia sembilan tahun, dan telah meninggal dunia di akhir tahun 2017 ketika menjalani kemoterapi fase konsolidasi (fase kedua).

\section{Desain}

Penelitian ini merupakan penelitian kualitatif dengan pendekatan fenomenologi deskriptif. Di dalam fenomenologi dekriptif, peneliti tidak mengintepretasikan secara bebas cerita yang diberikan partisipan, melainkan partisipanlah yang secara aktif memaknai kembali pengalaman hidupnya, lalu peneliti akan menulis deskripsi atas pemaknaan tersebut dan mengelompokkan tematema yang sejenis (Penner \& McClement, 2008). Pengalaman yang menjadi fokus dari penelitian ini adalah pengalaman menjalani peran ibu dari anak dengan LLA. Peneliti melakukan teknik bracketing dalam menggali informasi, di mana peneliti harus menyampingkan sudut pandang pribadi, pengetahuan teknis, maupun pengalaman yang familiar, dan menerima data dari partisipan sebagaimana adanya sesuai dengan pemaknaan partisipan (Penner \& McClement, 2008).

Sebagai bagian dari paradigma natural, di dalam penelitian fenomenologi, prinsip kepercayaan (trustworthiness) diutamakan (Guba, 1981). Prinsip kepercayaan ini terdiri atas prinsip kredibilitas (credibility), keteralihan (transferability), kebergantungan (dependability), dan kepastian (confirmability) dari proses penelitian (Guba, 1981; Schwandt, Lincoln, \& Guba, 2007). Dalam aspek kredibilitas, yaitu pembuktian bahwa metode yang digunakan adalah metode yang 
tepat, peneliti melakukan telaah jurnal fenomenologi dengan tema serupa, yaitu mengenai ibu dengan anak yang mengalami sakit kronis. Sementara itu, guna menunjang prinsip keteralihan, untuk penelitian selanjutnya, peneliti mendokumentasikan proses, hasil penelitian, serta referensi jurnal yang digunakan dalam penelitian ini secara rinci dan sistematis. Dalam prinsip keteguhan, peneliti mendokumentasikan setiap tahap penelitian dengan jelas untuk memastikan ketepatan alur penelitian. Pada prinsip kepastian, untuk memastikan data yang dikumpulkan objektif, peneliti menyusun rangkuman hasil temuan, kemudian melakukan konfirmasi kepada partisipan mengenai kesesuaian sudut pandang peneliti dengan apa yang dimaksud oleh partisipan.

\section{Prosedur}

Dalam pemilihan partisipan, peneliti menyebarkan informasi melalui aplikasi komunikasi daring. Setelah mendapatkan beberapa orang partisipan, peneliti melakukan wawancara awal untuk menjelaskan mengenai informasi yang dibutuhkan, sekaligus menawarkan bantuan psikologis melalui tenaga profesional kesehatan mental bagi partisipan yang membutuhkan. Berdasarkan wawancara tersebut, peneliti mendapati dua orang ibu yang mampu bercerita secara lancar mengenai pengalaman mereka dalam menjalani peran ibu dari anak yang mengidap LLA. Satu orang ibu memiliki anak yang mengidap LLA dan aktif menjalani pengobatan selama lima tahun, dan satu orang ibu telah kehilangan anaknya satu tahun sebelum pengambilan data dilakukan. Peneliti tetap melakukan pengambilan data kepada kedua partisipan untuk melihat apakah terdapat perbedaan pemaknaan dari ibu yang anaknya masih dalam kondisi sakit dan yang telah meninggal dunia.

Pengambilan data dilakukan dengan metode wawancara mendalam dan observasi. Wawancara dilakukan sebanyak dua kali dengan durasi 1.5-2 jam pada masing-masing ibu dan dilakukan di rumah kedua ibu. Seluruh sesi wawancara direkam untuk dibuat transkrip verbatim dan dianalisis. Untuk memastikan keakuratan data, peneliti menyusun rangkuman atas hasil temuan, kemudian meminta partisipan untuk melakukan verifikasi ketepatan data dan mengklarifikasi data yang kurang tepat.

\section{Teknik Analisis}

Beberapa tahap analisis dilakukan oleh peneliti, meliputi: membaca dan mendalami setiap cerita partisipan, menyusun catatan-catatan mengenai pengalaman partisipan, mengembangkan tema-tema yang muncul dalam cerita setiap partisipan, mencari hubungan lintas tema, menganalisa 
cerita partisipan, mencari pola yang sama dari berbagai tema yang muncul pada cerita partisipan, dan mengelompokkan kembali seluruh tema yang ditemukan.

\section{ANALISIS DAN HASIL}

Berdasarkan analisis data yang telah dilakukan oleh peneliti, tampak bahwa para ibu mengalami dinamika psikologis yang cukup kaya dalam pengalaman mereka menjalani peran ibu sekaligus perawat dari anak yang mengidap LLA. Dalam menjalani perannya sebagai ibu, mereka mengalami tema-tema yang unik, yang dinamakan oleh peneliti sebagai titik balik, proses pembelajaran, menerima dukungan, keterhubungan dengan Tuhan dan orang-orang senasib, tidak ada ibu yang sempurna, dan satu hal dalam satu waktu. Pada paparan di bawah ini, tema-tema yang muncul diurutkan mulai dari proses penetapan diagnosis awal hingga masa pengobatan anak mereka.

\section{Tema 1: Mengatasi Titik Balik Kehidupan}

Pada tahap penetapan diagnosis LLA, kedua ibu mengalami perasaan sedih, kaget dan bingung atas pernyataan dokter terhadap penyakit anak mereka. Di dalam kasus Ibu EM, ia merasa sedih dan kaget, sementara di dalam kasus Ibu RV, ia kaget dan menyalahkan dirinya sendiri atas kondisi sakit anaknya. Namun, kondisi tersebut tidak berlangsung lama. Baik ibu EM dan RV merasa perlu mengendalikan perasaan mereka dan fokus pada pengobatan anak mereka. Di masa inilah, mereka menghidupi tema mengatasi titik balik kehidupan.

Titik balik dimaknai sebagai pergantian fokus para ibu, dari perasan sedih, merasa bersalah, dan kaget kepada upaya-upaya untuk bertindak dengan cepat dan tepat dalam memberikan pengobatan terbaik pada anak mereka.

Rasanya hancur dek. Hancur sekali. Anak-anakku yang lain juga pada hancur. Kalau aku sih cuma sebentar aku gak berlarut-larut, aku dorong diriku sendiri harus semangat untuk anakku harus sembuh. (EM)

Saya pikir-pikir terus sepanjang waktu, saya berdoa dan bertanya sama Tuhan, sampai kemudian dalam prosesnya itu, saya sendirian dan saya tiba-tiba teringat bahwa... udah deh sampai di sini saja bertanya-tanyanya. Yang penting itu adalah saya mau anak ini sembuh. Saya mau anak saya bisa melalui ini semua, karena saya orangnya seperti itu. (RV) 


\section{Tema 2: Proses Pembelajaran}

Pada tahap awal pengobatan kemoterapi, kedua ibu tidak hanya menerima dengan pasrah kondisi sakit anaknya. Mereka berusaha secara mandiri mencari informasi dari berbagai sumber, baik dari buku-buku mengenai LLA pada anak, pengalaman dari sesama ibu dengan anak yang mengidap LLA, bahkan belajar dari anak-anak mereka untuk memahami lebih jauh apa yang harus mereka lakukan untuk mendukung anak mereka dalam proses pengobatan.

Kedua Ibu melihat bahwa pengalaman yang terjadi di dalam diri mereka memberikan kesempatan untuk belajar banyak hal mengenai kehidupan. Ibu RV yang berprofesi sebagai seorang dokter umum mencari informasi mengenai penyakit LLA yang diderita oleh anaknya. Ia berusaha untuk mengobservasi kondisi anaknya, juga anak-anak lain, berdiskusi dengan dokter, serta mencari informasi untuk membantu anaknya menjalani proses perawatan dalam kondisi yang baik.

Akhirnya karena penasaran saya baca berbagai teori soal LLA. Setiap kali saya ke rumah sakit saya bandingkan kondisi anak saya dengan anak-anak lain yang didiagnosis L1, L2, dan L3. Makanya saya tahu dengan yakin kondisi anak saya gimana saat ini. (RV)

Proses pembelajaran mengenai LLA juga tampak dalam pengalaman EM, ia menghubungi kenalannya yang pernah mengalami hal yang sama, dan meminta pendapat mengenai rumah sakit serta proses pengobatan yang harus dijalani oleh anaknya.

Nah sehari sebelum BMP datenglah tetanggaku,... waktu tau anakku sakit Leukemia aku ngomong sama dia, jadi dia datanglah mau menenangkan, sama orang ini juga aku belajar banyak soal proses yang harus dijalani, jadi bisa mempersiapkan diri. (EM)

Proses pembelajaran, tidak hanya berasal dari orang lain maupun media, kedua ibu merasa bahwa mereka mendapatkan pembelajaran dari perilaku anak yang sakit. Ibu EM melihat bahwa anaknya memiliki keyakinan yang kuat, optimis, dan disiplin, sehingga hal tersebut menginspirasinya untuk dapat tampil kuat dalam menjalani peran ibu sekaligus pengasuh.

Dia bilang... ah kakak pasti sembuh Ma, aku yakin bahwa Allah tuh baik sama aku. Itu nilai plus dirinya sendiri, dia gak pernah berlarut-larut, dia selalu yakin bahwa dia akan sembuh. Hal ini bikin aku jadi semakin semangat untuk jadi ibunya sekaligus membantu dia sembuh. (EM) 
Hal yang sama juga menjadi tema yang ada di dalam hidup ibu RV. Ia melihat bahwa proses perawatan yang dilakukan oleh anaknya merupakan proses yang sangat berat, tetapi ketahanan sang anak dalam menjalankan proses perawatan, sekalipun sangat menderita membuat ia kagum dan membuatnya belajar menjadi pribadi yang lebih tegar dalam menghadapi tantangan.

Untungnya anak saya itu anaknya bandel ya, tough. Cuma nangis sedih karena sakit tapi terus dia mau terus untuk jalanin. Kemoterapi itu sangat traumatik dan menyakitkan, saya tahu hanya anak saya yang bisa jalanin ini. Anak ini kuat, saya pun mau membantu dia. Saya bertekad untuk menjadi kuat. (RV)

\section{Tema 3: Menerima Dukungan}

Dalam pengalaman menjalani peran ibu, kedua partisipan menerima dukungan dari lingkungan sosial terdekat. Dukungan sosial ini membuat kedua partisipan merasa sanggup untuk menjalani peran ganda mereka di dalam keluarga.

Lingkunganku support, suamiku sendiri sangat support. Sempet ngerasa bersalah sih sama anak-anakku ini, tapi ya itu suami sama keluarga dan lingkunganku support... Dengan saya dapat support dari berbagai pihak, anak saya pun penuh semangat, saya pun gak tenggelam dalam kesedihan saya. (EM)

Oh, sangat supportif. Keluarga dan teman yang jauh dan dekat semua banyak menolong. Kurang lebihnya sih ya udah lah gak masalah ya, tapi saya lihat keluarga besar sangat supportif. Mereka doanya gak berhenti dan sangat hands on untuk membantu adik-adiknya Kakak, jadi saya juga bisa membagi fokus saya dan lebih banyak waktu untuk mengawasi pengobatan si Kakak. (RV)

\section{Tema 4: Keterhubungan dengan Tuhan dan Orang-Orang Senasib}

Selama mendampingi anak yang mengidap LLA, kedua ibu mengaku lebih banyak membangun relasi dengan Tuhan dan sesama. Dalam keseharian mereka, kedua ibu mengaku bahwa mereka lebih banyak berkomunikasi dengan Tuhan melalui doa dan ibadah. Hal ini dilakukan karena menjalani peran ganda sebagai ibu merupakan perjalanan yang penuh dengan ketidakpastian, sehingga mereka merasa perlu mendekatkan diri kepada Tuhan sebagai sumber kekuatan dan pertolongan mereka.

Menjalani ini semua, saya selalu berdoa ya sama Tuhan. Ya sama siapa lagi kan yang paling memahami diri kita dan tau beratnya jadi kita? Cuma Tuhan... Aku 
lebih dekat dengan tuhan, lebih percaya bahwa semua terjadi di hidupku itu udah disediakan semuanya... Saya merasa sebagai manusia saya dipelihara Tuhan secara luar biasa. Setiap butuh pasti ada. (EM)

Semenjak Anakku sakit kan perjuangannya berat ya. Saya semakin sering ngobrol sama Allah. Saya percaya sama doa, berkali-kali saya doakan dan banyak hal terjadi... Melewati itu semua, ada aja perpanjangan tangan tuhan dalam segala hal. Mau untuk merawat anak-anak lain, biaya, selalu ada aja. Hal ini bikin saya yakin bahwa saya harus menjalani semua ini. (RV)

Selain membangun relasi yang lebih dalam dengan Tuhan, kedua ibu juga mengembangkan pikiran reflektif yang membantu mereka untuk mengembangkan diri. Ketika melihat perjuangan sesama ibu dari anak yang mengidap leukemia, kedua ibu merasa terpanggil untuk memberikan bantuan kepada sesama. Keduanya memaknai bahwa mereka diberikan kekuatan oleh Tuhan untuk menghadapi hal ini agar dapat lebih berguna bagi sesama. Hal ini membuat kedua ibu berperan aktif di manapun mereka berada, untuk turut membantu dan mendampingi sesama kaum ibu dalam menjalani peran mereka.

Sekarang kalau di Dharmais ada orang tua yang anaknya kritis, saya suka dimintai tolong dokter-dokter untuk datang dan kasih dukungan... Saya merasa saya berguna, saya nemenin orang tuanya, anaknya juga saya ajak ngobrol, pokoknya saya merasa saya belajar menjadi manusia yang lebih baik dengan menolong orang lain. (EM)

Saya merasa saya harus berbagi dengan orang lain tentang hal ini, saya merasa dibentuk jadi manusia yang lebih baik... Makanya saya punya keterikatan sama orang-orang dengan kanker... jadi sebisa mungkin saya cerita dan berbagi... Kalau ada yang nanya akan saya jawab dan kasih edukasi, karena sel kanker itu semakin cepet ketauan semakin baik kan... jadi sebisa mungkin saya cerita dan berbagi. (RV)

\section{Tema 5: Tidak Ada Ibu yang Sempurna}

Dalam menemani proses kemoterapi dari anak-anak mereka, para ibu tetap menjalani peran domestik, seperti mengurus rumah tangga, mengasuh anak-anak mereka yang lain, menjalani peran sebagai istri, dan merawat anak mereka yang sakit. Dalam hal ini, kedua ibu menerima kondisi bahwa mereka belum dapat menjalani peran ibu secara sempurna. Mereka lebih banyak memfokuskan perhatian kepada anak mereka yang sakit, sehingga kerap kesulitan membagi fokus dengan anak mereka yang lain. Meskipun mereka mengakui adanya perasaan bersalah, tetapi 
pemaknaan mereka berkembang secara lebih mendalam. Kedua ibu ini mempercayakan pengasuhan anak-anak mereka yang sehat kepada suami dan keluarga besar, mereka memiliki kesadaran bahwa mereka memang bukan ibu yang sempurna, tetapi mereka masih bisa terus berusaha untuk menjadi ibu yang baik bagi seluruh anaknya.

Jadi ya udah memang pasti gak adil, tapi kalau ada kesempatan ya saya selalu berusaha jadi yang terbaik buat semua, anak-anakku liat itu kok, mereka jadi pengertian... Mereka mengerti bahwa aku ini sayang sama mereka, tapi nggak bisa melakukan lebih... Aku fokus ke anakku yang sakit, suamiku fokus ke beres-beres rumah, urusin anak dll. Karena dia gak kuat juga kalo urus anak yang sakit. Kami bagi-bagi tugas, jadi tim kerja yang solid... Saya nggak sempurna memang jadi ibu, tapi semua mendukung saya untuk menjalani ini. (EM)

Saya sama semua anak-anak saya semakin deket, yang dua itu sayang sekali sama kakaknya, kalau kakaknya masuk rumah sakit, dua anak itu bisa nangis karena sedih. Ya pasti waktu untuk mereka kurang ya, sama suami juga kurang, tapi saya sadar bahwa ini memang waktunya saya sama yang sulung, nanti ada waktunya saya fokus sama adik-adiknya, suamiku juga pengertian. Kami masih quality time terus kok, ya walau keluarga ini gak ideal tapi saya selalu berusaha buat nemenin semuanya satu-satu sesuai kebutuhan mereka... Kalau saya udah mulai sedihsedih, ya saya liat orang di sekitar saya yang anaknya gak sakit, tapi ibunya sibuk sendiri. Memang sih nggak ada ibu yang sempurna, yang saya tau saya jalanin dan lakuin yang terbaik yang saya bisa. (RV)

\section{Tema 6: Satu Hal di dalam Satu Waktu}

Kondisi anak yang mengidap LLA tidaklah stabil. Hal ini membuat para ibu tampil siaga dalam menyikapi berbagai perubahan kondisi anak mereka. Dalam menjalani peran sebagai seorang ibu di tengah ketidakstabilan kondisi kesehatan anaknya, para ibu merasa harus menjalani kehidupan secara perlahan, satu hal dalam satu waktu. Mereka belajar untuk bersabar dan lebih adaptif dalam menghadapi berbagai perubahan yang ada di dalam hidup mereka. Seperti yang dikatakan oleh salah satu partisipan, di mana ia merasa hidup mengajarkannya untuk menjalani semua hal secara sabar dan sadar, satu hal di dalam satu waktu, hal ini menurut salah satu partisipan dirasakan sebagai cara Tuhan membentuk mereka untuk hidup secara lebih baik.

Do life one thing at a time... Menjalani hari bersama anak saya itu gak bisa mikir rumit dan jauh-jauh. Terutama kondisi kesehatan kan gak stabil ya, suka infeksi, demam, dll. Pokoknya bangun pagi saya bilang sama diri sendiri bahwa hari ini saya mau lakukan terbaik untuk anak ini dan anak-anak saya lainnya, yasudah 
hasil akhirnya kita lihat saja nanti. Kemudian kalau saya lihat ke belakang... wah banyak yah hari yang sudah berhasil kami jalani. (RV)

Saya sekarang lebih percaya bahwa semua terjadi di hidupku itu udah disediakan semuanya. Saya gak boleh takut, saya harus sabar dan sadar akan berkat dan penyertaannya Tuhan, pokoknya jalani satu-satu. (EM)

Menurut kedua ibu, mereka diajarkan untuk menjalani hidup secara sadar dan sabar, yang terangkum dalam tema satu hal dalam satu waktu. Hal ini membuat mereka dapat menjalani hari yang buruk, dan hari yang baik dengan bersyukur. Sudut pandang positif sangat kuat pada kedua pribadi ini, dimana mereka tidak fokus pada berbagai emosi negatif, melainkan dapat mengembangkan regulasi diri yang baik sehingga dapat menjalankan peran ganda sebagai ibu secara maksimal.

\section{DISKUSI}

Penelitian ini bertujuan untuk memahami pengalaman menjalani peran ibu dari anak yang mengidap LLA. Berdasarkan hasil wawancara, didapatkan beberapa tema dalam pemaknaan pengalaman mereka menjalani peran ibu. Sekalipun kedua ibu memiliki karakteristik yang sedikit berbeda, di mana anak ibu RV masih hidup dan baru mulai menjalani kemoterapi di fase perawatan, sementara anak ibu EM telah meninggal dunia pada tahun 2017, tetapi keduanya memunculkan tema-tema sentral yang sama. Hal ini mengindikasikan bahwa secara umum, tema yang berhasil dikumpulkan peneliti adalah tema yang muncul dalam pengalaman seorang ibu dengan anak yang mengidap leukemia.

Kedua ibu yang menjadi narasumber di dalam penelitian ini tampak memiliki sudut pandang yang positif dalam menghadapi kondisi kesehatan anak mereka. Mereka menerima kondisi kesehatan anak mereka, memberi ruang bagi kesedihan mereka, tetapi berusaha untuk mencari makna yang positif guna membantu diri mereka untuk menjalankan peran sebagai ibu sekaligus perawat dari anaknya yang mengidap leukemia. Tema mengatasi titik balik kehidupan dan proses pembelajaran mengindikasikan adanya kemampuan di dalam diri kedua ibu untuk mengolah emosi dan memfokuskan diri pada tugas-tugas yang harus ia lakukan dalam menjalani peran ganda di dalam keluarga. Hal ini mengindikasikan adanya kualitas keterampilan memecahkan masalah yang kuat di dalam diri mereka dalam menyikapi masa penyesuaian diri ketika menerima diagnosis LLA 
pada anaknya, sehingga dapat menjalani peran ganda dengan efektif. Keterampilan memecahkan masalah memang merupakan sebuah bekal yang dibutuhkan oleh para ibu dengan anak yang mengidap leukemia. Hal ini sejalan dengan penelitian Sahler dkk. (2013) mengenai pemberian pelatihan keterampilan memecahkan masalah kepada ibu yang baru menerima diagnosis leukemia pada anak mereka. Berdasarkan penelitian tersebut, para ibu yang diberikan pelatihan keterampilan memecahkan masalah berhasil mengurangi afek negatif, seperti depresi, kecemasan, maupun gejala PTSD.

Dalam penelitian ini, kedua partisipan mendapatkan banyak dukungan sosial dari lingkungan sekitarnya. Hal ini terlihat dalam tema menerima dukungan, di mana kedua ibu merasa bahwa lingkungan sosial sangat membantu mereka menjalani berbagai situasi, sehingga mereka tidak mengalami kesepian maupun rasa kosong dan putus asa, seperti yang biasa terjadi pada kondisi duka kronis. Hal ini berbeda dengan hasil penelitian Nikfarid, Rassouli, Borimnejad, dan Alavimajd (2017) yang mengatakan bahwa para ibu mengalami duka sejak menerima diagnosis leukemia pada anaknya dan terus berlanjut ketika ia menjalani peran ganda. Kondisi duka ini disebabkan oleh minimnya dukungan sosial, baik dari suami, maupun keluarga besar, mengingat pada budaya Iran, perempuan dituntut untuk mampu mengurus suami dan keluarganya sendiri.

Budaya keluarga Indonesia yang pada umumnya menjunjung gaya hidup yang guyub merupakan faktor protektif bagi kedua ibu dalam menghadapi kondisi duka kronis. Dukungan yang dirasa berguna bagi kedua ibu tersebut berasal dari suami, keluarga besar, teman-teman, dan tenaga medis yang merawat anak mereka. Adapun bentuk dukungan yang mereka dapatkan berupa dukungan moril, seperti memberikan semangat dan doa, maupun dalam bentuk kesediaan untuk mengasuh dan merawat anak lainnya yang sehat. Di samping itu, informasi yang diberikan oleh tenaga kesehatan kepada para ibu juga diasosiasikan sebagai bentuk dukungan yang membuat ibu merasa lebih tenang dalam mendampingi pengobatan anaknya (Bozo, Anahar, Ates, \& Etel, 2009).

Di samping itu, tema keterhubungan dengan Tuhan dan orang-orang senasib mengindikasikan adanya religious coping strategy yang digunakan untuk memaknai kondisi sakit anak secara positif dan memunculkan dorongan untuk menjadi penolong bagi para ibu dengan nasib yang sama. Hal ini sejalan dengan penelitian Widayanti (2012) yang menyatakan bahwa penggunaan religious coping strategy pada ibu dengan anak yang mengidap sakit kronis dapat membantu para ibu untuk menerima kondisi kesehatan anak mereka yang tidak ideal, dan menyadari bahwa Tuhan memegang kontrol atas segala hal yang terjadi di dalam hidup mereka. Sistem keyakinan para ibu merupakan sebuah saringan untuk menyeimbangkan cara mereka 
bertindak di dalam kehidupan, serta memengaruhi harapan mereka tentang hasil dari berbagai perawatan medis yang dilakukan. Pada kasus ibu EM, sekalipun ia harus kehilangan anaknya di dalam proses pengobatan, hal ini dimaknai secara positif. Ibu EM merasa telah melakukan berbagai upaya yang dapat dilakukan manusia, yaitu merawat anaknya yang sakit dan menolong sesama yang membutuhkan. Sementara kematian anaknya merupakan bagian dari rencana Tuhan yang baik bagi hidupnya.

Pada tema tidak ada ibu yang sempurna, dan satu hal di dalam satu waktu, kedua ibu tersebut tampak dapat menerima bahwa kondisi yang mereka jalani saat ini jauh dari ideal dan bahwa mereka tidak dapat menjalani peran ganda mereka secara sempurna. Kedua ibu memiliki kesadaran untuk hidup di masa kini dan melakukan berbagai upaya semampu mereka. Hal ini mengindikasikan adanya mindfulness parenting yang diterapkan di dalam kehidupan mereka seharihari. Mindfulness parenting didefinisikan sebagai upaya untuk memperhatikan dan hadir pada momen saat ini, menampilkan penerimaan, kebaikan, dan belas kasih selama menjalani peran sebagai orang tua (Siu, Ma, \& Chui, 2016). Pendekatan mindfulness pada orang tua dari anak-anak yang mengidap sakit kronis berhasil menurunkan tingkat kecemasan dan depresi, serta secara signifikan memperbaiki kualitas hubungan di antara ibu dengan dirinya sendiri, dengan anggota keluarga, dan meningkatkan fungsi sosial mereka. Pada kedua ibu yang menjadi partisipan, menjalani hidup secara bertahap dan menghidupi momen masa kini membantu mereka untuk menjalani hidup secara sadar, sabar, perlahan, dan membantu mereka merasa lebih sehat secara mental.

Dalam proses penelitian ini, peneliti melihat bahwa kondisi kedua anak partisipan berbeda. Anak partisipan RV telah berhasil melalui tahap-tahap kemoterapi di fase yang berat dan intens, yaitu induksi dan konsolidasi, dan saat ini sedang mulai menjalani tahap kemoterapi yang bersifat perawatan. Sementara itu, anak partisipan EM telah meninggal pada 25 Desember 2017. Meski begitu, kedua ibu menceritakan pemaknaan pengalaman yang cukup sama satu sama lain. Hal ini mengindikasikan bahwa tema-tema yang diambil telah merepresentasikan perjalanan mereka dalam menjalani peran ibu dari anak dengan leukemia. Di sisi lain, kondisi anak ibu RV yang stabil serta anak ibu EM yang telah meninggal dunia dapat menjadi landasan mengapa kedua ibu memaknai pengalaman keduanya secara sangat positif, yaitu karena mereka telah melalui masa-masa paling kritis dalam proses pengobatan anak mereka. 


\section{SIMPULAN DAN SARAN}

\section{Simpulan}

Sebagai seorang ibu, menerima kondisi anak yang mengidap penyakit kronis, dalam hal ini leukemia, tentu bukan hal yang mudah dan sangat memengaruhi cara ibu dalam menjalani dan memaknai pengalamannya. Melalui penelitian ini, peneliti berhasil mengumpulkan tema-tema besar dari perjalanan hidup kedua ibu partisipan penelitian, yaitu titik balik, proses pembelajaran, menerima dukungan, keterhubungan dengan Tuhan dan orang-orang senasib, tidak ada ibu yang sempurna, serta satu hal dalam satu waktu. Melalui tema-tema ini, dapat dipahami bahwa kedua ibu memandang kondisi sakit pada anak mereka sebagai sebuah perjuangan, kesempatan untuk belajar menjadi manusia yang lebih baik, menjalani peran ibu semaksimal mungkin, serta menjalani perjuangan mereka secara sabar, sadar, dan bersyukur atas kemudahan yang mereka dapatkan dari Tuhan. Di samping itu, hal yang menjadi kunci keberhasilan para ibu dalam menjalani peran ganda mereka adalah ketersediaan dukungan sosial, baik dari keluarga, kerabat, teman, bahkan dari para ibu yang memiliki pengalaman serupa. Lebih jauh, setelah mengalami sulitnya menjalani peran ibu dari anak yang mengidap LLA, kedua ibu terpanggil untuk membantu ibu lainnya dalam menghadapi isu yang sama.

\section{Saran Teoretis}

Peneliti melihat perlu pula dilakukan penelitian fenomenologi pada para ibu yang anakanaknya masih berada tahap pengobatan induction dan consolidation, di mana ketidakstabilan kesehatan serta tekanan yang dihadapi lebih intens, sehingga dapat dipahami dinamika psikologis yang terjadi, serta melahirkan saran-saran yang lebih komprehensif untuk membantu ibu-ibu dalam menyikapi distres psikologis mereka. Penelitian fenomenologis mengenai pemaknaan pengalaman ayah dari anak yang mengidap leukemia juga perlu dilakukan untuk memahami dinamika psikologis yang dialami ayah dalam menjalani perannya.

\section{Saran Praktis}

Salah satu implikasi penelitian ini bagi para praktisi klinis yang bekerja dengan penderita kanker pada anak adalah untuk mengetahui secara mendalam dinamika psikologis yang dialami oleh orang tua, terutama ibu, dari anak yang mengidap leukemia. Saran praktis bagi institusi kesehatan adalah agar menyediakan layanan profesional kesehatan mental yang mudah diakses bagi 
para ibu yang mendampingi proses kemoterapi anaknya. Hal ini diperlukan karena efek samping kemoterapi yang berat bagi anak maupun ibu, serta ketidakstabilan kondisi fisik dan mental anak yang sangat memengaruhi kualitas kesehatan mental ibu, yang pada akhirnya dapat berimbas pula pada peran ibu di dalam keluarga.

Dengan mempertimbangkan pentingnya kesehatan mental keluarga dari anak yang mengidap LLA, maka pihak rumah sakit dapat memfasilitasi kegiatan-kegiatan sederhana berlandaskan terapi keluarga yang dapat diikuti oleh keluarga inti dari anak yang sedang dirawat di rumah sakit. Hal ini penting dilakukan untuk membuat seluruh anggota keluarga mendapatkan dampak positif dari interaksi terapeutik di dalam keluarga dan membantu menjaga kesehatan mental mereka.

Dalam kaitannya dengan kondisi kesehatan mental ibu dengan anak yang mengidap leukemia, maka dibutuhkan pembentukan kelompok dukungan sosial yang juga diawasi oleh praktisi kesehatan. Di dalam kelompok ini, dapat dibagikan informasi seputar penanganan leukemia pada anak, efek samping kemoterapi pada anak, dampak kondisi sakit anak pada dinamika kehidupan keluarga, serta informasi mengenai pihak-pihak yang menyediakan layanan konseling bagi keluarga yang terdampak leukemia.

\section{REFERENSI}

Bally, J. M. G., Duggleby, W., Holtslander, L., Mpofu, C., Spurr, S., Thomas, R., \& Wright, K. (2014). Keeping hope possible. Cancer Nursing, 37(5), 363-372. doi: 10.1097/ncc.0b013e3182a453aa

Behrman, R. E., Kliegman, R. M., Arvin, A. M. (2000). Ilmu kesehatan anak nelson (15 ${ }^{\text {th }}$ ed., Vol. 3). Jakarta: Penerbit Buku Kedokteran EGC.

Bozo, Ö., Anahar, S., Ateş, G., \& Etel, E. (2009). Effects of illness representation, perceived quality of information provided by the health-care professional, and perceived social support on depressive symptoms of the caregivers of children with leukemia. Journal of Clinical Psychology In Medical Settings, 17(1), 23-30. doi: 10.1007/s10880-009-9177-4

Cicogna, E., Nascimento, L., \& Lima, R. (2010). Children and adolescents with cancer: Experiences with chemotherapy. Revista Latino-Americana De Enfermagem, 18(5), 864872. doi: 10.1590/s0104-11692010000500005 
Coniglio, S., \& Blackman, J. (1995). Developmental outcome of childhood leukemia. Topics In Early Childhood Special Education, 15(1), 19-31. doi: 10.1177/027112149501500104

Cooper, S., \& Brown, P. (2015). Treatment of pediatric acute lymphoblastic leukemia. Pediatric Clinics of North America, 62(1), 61-73. doi: 10.1016/j.pcl.2014.09.006

Davis, A., Viera, A., \& Mead, M. (2014). Leukemia: An overview for primary care. American Family Physician, 89(9), 731-738.

Fianza, P. I. (2006). Leukemia limfoblastik akut. Dalam Sudoyo, A. W., Setiyohadi, B., Alwi, I., Simadibrata, M., \& Setiadi, S. (4th ed.). Buku ajar ilmu penyakit dalam (hlm. 1266-1275). Jakarta: Interna Publishing.

Florian, V., \& Krulik, T. (1991). Loneliness and social support of mothers of chronically ill children. Social Science \& Medicine, 32(11), 1291-1296. doi: 10.1016/02779536(91)90045-e

Guba, E. G. (1981). Criteria for assessing the trustworthiness of naturalistic inquiries. Educational Communication and Technology, 29(2), 75-91. doi: 10.1007/BF02766777

Himawan, K. K., Bambling, M., \& Edirippulige, S. (2017). Modernization and singlehood in Indonesia: Psychological and social impacts. Kasetsart Journal of Social Sciences. 1-8. doi: 10.1016/j.kjss.2017.09.008

Hussain, A., Ahmad, N., Manzoor, R., \& Hameed, M. (2015). Impact of modernization on gender roles: A study of advocates in muzaffar garh. International Letters Of Social and Humanistic Sciences, 52, 15-22. doi: 10.18052/www.scipress.com/ilshs.52.15

Katooa, N., Shahwan, L. J., Reece, \& Jones, L. (2015). Characteristics of mothers with chronically ill children in jeddah, saudi arabia. International Journal of Nursing, 2(1), 59-73. doi: 10.15640/ijn.v2n1a7

Kurnianda, J. (2006). Leukemia mieloblastik akut. Dalam Sudoyo, A. W., Setiyohadi, B., Alwi, I., Simadibrata, M., \& Setiadi, S. (4th ed.). Buku ajar ilmu penyakit dalam (pp. 706-709) Jakarta: Interna Publishing.

Lubkin, I. M., \& Larsen, P. D. (2013). Chronic illness (9th ed.). Burlington, NJ: Jones \& Bartlett Learning.

Macedo, E., Silva, L., Paiva, M., \& Ramos, M. (2015). Burden and quality of life of mothers of children and adolescents with chronic illnesses: An integrative review. Revista Latino Americana De Enfermagem, 23(4), 769-777. doi: 10.1590/0104-1169.0196.2613 
Major, D. (2003). Utilizing role theory to help employed parents cope with children's chronic illness. Health Education Research, 18(1), 45-57. doi: 10.1093/her/18.1.45

Maria, A., Indriati, G., \& Rahmalia, S. (2014). Pengalaman ibu dalam merawat anak dengan leukemia. Jurnal Online Mahasiswa Program Studi Ilmu Keperawatan Universitas Riau, $1(1), 1-7$.

Masako, I. K. (2003). Motherhood. Dalam Ponzetti, J. J. (2nd ed.). International encyclopedia of marriage and family (hlm. 1146-1151). New York, NY: Macmillan Reference USA.

Nayak, B., Cornelio, S., \& George, A. (2016). Experiences of mothers on parenting children with leukemia. Indian Journal Of Palliative Care, 22(2), 168. doi: 10.4103/0973-1075.179608

Nikfarid, L., Rassouli, M., Borimnejad, L., \& Alavimajd, H. (2017). Experience of chronic sorrow in mothers of children with cancer: A phenomenological study. European Journal Of Oncology Nursing, 28, 98-106. doi: 10.1016/j.ejon.2017.02.003

Nurhamida, Y. (2013). Power in marriage pada ibu bekerja dan ibu rumah tangga. Jurnal Psikogenesis, 1(2), 185-198. doi: 10.24854/jps.v1i2

Penner, J., \& McClement, S. (2008). Using phenomenology to examine the experiences of family of patients with advanced head and neck cancer: Reflections of a novice researcher. International Journal Of Qualitative Methods, 7(2), 92-101. doi: 10.1177/160940690800700206

Pusat Data dan Informasi. (2015). Situasi penyakit kanker. Jakarta: Kementrian Kesehatan RI.

Ramya, V., \& Lakshmi, S. (2019). A methodical review of diagnosis and classification of leukemia using blood microscopic images. International Conference on Communication and Signal Processing. 258-262. doi: 10.1109/iccsp.2019.8698075

Rokhaidah, \& Herlina. (2018). Studi fenomenologi pengalaman orangtua dalam merawat anak dengan diagnosis kanker. Jurnal Kedokteran dan Kesehatan, 14(2), 31-38. doi:10.24853/jkk.14.2.31-38

Sahler, O., Dolgin, M., Phipps, S., Fairclough, D., Askins, M., Katz, E., ... Butler, R. W. (2013). Specificity of problem-solving skills training in mothers of children newly diagnosed with cancer: Results of a multisite randomized clinical trial. Journal Of Clinical Oncology, 31(10), 1329-1335. doi: 10.1200/jco.2011.39.1870

Schwandt, T. A., Lincoln, Y. S., \& Guba, E. G. (2007). Judging interpretations: But is it rigorous? Trustworthiness and authenticity in naturalistic evaluation. New Directions for Evaluation, 114, 11-25. doi: 10.1002/ev.223 
Sherief, L., Kamal, N., Abdalrahman, H., Youssef, D., Alhady, M., Ali, A., .. Hashim, H. M. (2015). Psychological impact of chemotherapy for childhood acute lymphoblastic leukemia on patients and their parents. Medicine, 94(51), e2280. doi: 10.1097/md.0000000000002280

Siu, A., Ma, Y., \& Chui, F. (2016). Maternal mindfulness and child social behavior: The mediating role of the mother-child relationship. Mindfulness, 7(3), 577-583. doi: 10.1007/s126710160491-2

Wahab, S. (2000). Ilmu kesehatan anak (15th ed.) Jakarta: Penerbit Buku Kedokteran EGC.

Widayanti, C. G. (2012). The perceived role of god in health and illness: The experience of javanese mothers caring for a child with thalassemia. Jurnal Psikologi, 9(1), 65-72. 